15. Sies H. Role of metabolic $\mathrm{H} 2 \mathrm{O} 2$ generation: redox signaling and oxidative stress / H. Sies // The Journal of biological chemistry. - 2014. - V. 289. - P. 8735-8741.

16. Oshino N. Optical measurement of the catalase-hydrogen peroxide intermediate (Compound I) in the liver of anaesthetized rats and its implication to hydrogen peroxide production in situ / N. Oshino, D. Jamieson, T. Sugano, B. Chance // The Biochemical journal. - 1975. - V. 146. - P. 67-77.

17. Enyedi B. H2O2: a chemoattractant? / B. Enyedi, P. Niethammer // Methods in enzymology. - 2013. - V. 528. P. 237-255.

18. Hayden M. S. NF-kappaB in immunobiology / M. S. Hayden,S. Ghosh // Cell research. - 2011. - V. 21. P. 223-244.

19. Tsybulin O. GSM $900 \mathrm{MHz}$ microwave radiation affects embryo development of Japanese quails / O. Tsybulin, E. Sidorik, S. Kyrylenko et al. // Electromagnetic biology and medicine. - 2012. - V. 31. - P. 75-86.

20. Tsybulin O. GSM $900 \mathrm{MHz}$ cellular phone radiation can either stimulate or depress early embryogenesis in Japanese quails depending on the duration of exposure / O. Tsybulin, E. Sidorik, O. Brieieva et al. // International journal of radiation biology. - 2013. - V. 89. - P. 756-763.

21. Calabrese E. J. Hormesis: why it is important to toxicology and toxicologists / E. J. Calabrese // Environ Toxicol Chem. - 2008. - V. 27. - P. 1451-1474.

Цыбулин Александр. Влияние микроволнового излучения на состояние антиоксидантной системы перепелиных эмбрионов и суточного молодняка. Длительное воздействие на человека низкоинтенсивного радиочастотного электромагнитного излучения приводит к достоверному увеличению риска возникновения раковых опухолей. Механизмы таких эффектов не ясны, но во многих работах указывается на признаки окислительного стресса в живых клетках под воздействием радиочастотного электромагнитного излучения. Целью нашего исследования было изучение влияния микроволнового излучения на состояние антиоксидантной системы в тканях перепелиных эмбрионов и суточного молодняка. Эмбрионы перепела японского подвергались in ovo низкоинтенсивному микроволновому облучению GSM 900 МГц (14 мкВт/см²) в течение 158-456 ч (48 c - ON, 12 c - OFF) до и на начальных этапах развития. Было продемонстрировано достоверное окислительное воздействие микроволнового излучения на модели перепелиных эмбрионов. Эффект проявляется в повышенном уровне перекисного окисления липидов и снижение активности ключевых ферментов антиоксидантной системы.

Ключевые слова: микроволновое излучение, мобильный телефон, эмбриогенез, окислительный стресс, антиоксиданты.

Tsybulin Olexandr. Influence of Microwave Radiation on Antioxidant System in the Tissues of Embryos and Daily Quail. Long-term exposure of humans to low intensity radiofrequency electromagnetic radiation (RF-EMR) leads to a statistically significant increase in tumor incidence. Mechanisms of such the effects are unclear, but features of oxidative stress in living cells under RF-EMR exposure were previously reported. The aim of our study was to investigate the effect of microwave radiation on the state of the antioxidant system in the tissues of embryo and daily quail. Embryos of Japanese quails were exposed in ovo to extremely low intensity RF-EMR of GSM $900 \mathrm{MHz}$ $\left(14 \mu \mathrm{W} / \mathrm{cm}^{2}\right)$ during $158-456 \mathrm{~h}$ discontinuously (48 c - ON, $12 \mathrm{c}-\mathrm{OFF}$ ) before and in the initial stages of development. Significant oxidative effect of microwave radiation on the model of quail embryos was demonstrated. The effect was manifested in increased level of lipid peroxidation and decreased activity of key enzymes of antioxidant system.

Key words: microwave radiation, mobile phone, embryogenesis, oxidative stress, antioxidants.

Стаття надійшла до редколегії 03.09.2016 р.

УДК 616.155.194.8-056.5: 616-06: 618.11-008.64: 618.17

Аліна Литвиненко,
Марія Ступчук,
Орест Блашків,
Тетяна Вознесенська

\title{
Морфофункціональний стан жіночої репродуктивної системи за умов застосування наночастинок срібла
}

За умов одно-, п'яти- та десятикратного внутрішньовенного введення наночастинок срібла (2 мг/кг та 4 мг/кг) оцінювали мейотичне дозрівання ооцитів, а також за умов десятикратного внутрішньовенного введення наночастинок срібла (2 мг/кг та 4 мг/кг) - пре- й постімплантаційну смертність ембріонів у мишей.

() Литвиненко А., Ступчук М., Блашків О., Вознесенська Т., 2016 
Дослідження (дві серії) проведено на самках білих лабораторних мишей восьми тижнів (16-18 г). Використовувані наночастинки срібла (AgNPs, 30 нм, концентрація - 8 мг/мл за металом, форма - сферична).

Уперше отримано дані про те, що однократне й п'ятикратне введення AgNPs (2 мг/кг, 4 мг/кг) не викликає запалення, не впливає на ооцити, змінює функціональний стан фолікулярних клітин і скоротливість матки.

10-кратне введення AgNPs (2 мг/кг, 4 мг/кг) приводить до розвитку запальної реакції й пригнічує оваріальну функцію (формування полярного тільця ооцитів, збільшує кількість апоптотичних і некротичних клітин у фолікулярному оточенні ооцита), змінює функціональний стан матки (зростає скоротливість оваріального й цервікального відділів матки), проте не впливає на розвиток пре- й постімплантаційних ембріонів.

Ключові слова: ооцити, матка, ембріони, наночастинки срібла.

Постановка наукової проблеми та ії значення. В останнє десятиліття значно збільшилося використання наночастинок срібла (AgNPs), а його загальне виробництво у світі оцінюється у 500 тонн на рік [6]. AgNPs мають металевий елементний склад, не містять кисень, проте поверхня металевих AgNPs окислюється за більшості умов навколишнього середовища й негативно заряджені гідроксота оксогрупи викликають негативний поверхневий заряд частинки. AgNPs певною мірою розчиняються у водному середовищі [3].

Є дані токсичності AgNPs на бактерії, водні організми й клітини еукаріот in vitro [2]. Саме значні відмінності токсичності AgNPs: 275-кратне для клітин ссавців і 500-кратне для бактерій у дослідах in vitro й збільшення обсягів виробництва НЧ ставлять завдання оцінки екологічних ризиків та загрози здоров'ю людини нанотехнологій.

Вплив AgNPs на клітини й тканини ссавців потребує детального з'ясування. Дані про вплив внутрішньовенного введення AgNPs на функціональний стан органів жіночої репродуктивної системи у ссавців на сьогодні відсутні.

Мета роботи - за умов одно-, п'яти- та десятикратного внутрішньовенного введення наночастинок срібла (2 мг/кг та 4 мг/кг) дослідити морфофункціональні особливості органів репродуктивної системи в самок мишей, а саме оцінити мейотичне дозрівання ооцитів, життєздатність клітин фолікулярного оточення ооцита, спонтанну скоротливу активність міометрію оваріального та цервікального відділів матки, а також за умов десятикратного внутрішньовенного введення наночастинок срібла (2 мг/кг та 4 мг/кг) - пре- й постімплантаційну смертність ембріонів у мишей.

Матеріали та методи дослідження. Дослідження (дві серії) проведено на самках білих лабораторних мишей восьми тижнів (16-18 г) із дотриманням усіх вимог щодо роботи з лабораторними тваринами (Міжнародна європейська конвенція про захист хребетних тварин, Страсбург, 1986). Після завершення експериментів тварин наркотизували нембуталом й умертвляли методом дислокації шийних хребців.

Характеристика наночастинки AgNPs - 30 нм (концентрація - 8 мг/мл за металом, форма сферична, колір коричневий, реагенти використані для синтезу - нітрат срібла $\left(\mathrm{AgNO}_{3}\right),(\mathrm{BioX}$ tra, $>99 \%$ (titration, Sigma-Aldrich); Карбонат калію $\left(\mathrm{K}_{2} \mathrm{CO}_{3}\right)(99,995 \%$ trace metals basis, Sigma-Aldrich); Танін (ACS reagent, Sigma-Aldrich) синтезовані в Інституті біоколоїдної хімії ім. Ф. Д. Овчаренка НАН України за оригінальним протоколом (методом хімічної конденсації).

Cерія перша. AgNPs - розводили у воді для ін'єкцій. Досліджували дві дози 2 мг/кг і 4 мг/кг. Спосіб уведення - внутрішньовенний. Кратність уведення для кожної дози $-1,5$ та 10 разів (n=8 тварин у кожній групі). Інтервал уведення - один раз на добу. Контрольним тваринам уводили фізіологічний розчин. Матеріал для дослідження (яєчники, матку) забирали на наступний день після останнього введення AgNPs.

Культивування ооцитів. Із яєчників мишей неферментативно (механічно) виділяли ооцити (без кумулюсних клітин і в складі кумулюсно-ооцитарних клітинних комплексів). Ооцити від мишей однієї групи збирали та розподіляли в окремі камери по 10-20 ооцитів у кожній. Усі контрольні та експериментальні ооцити культивували в однакових умовах (стерильний бокс, камери по 0,4 мл культурального середовища DME 315 мM HEPES, концентрація $\mathrm{Ca}^{2+}-1,71 \mathrm{мM}$, температура $-37{ }^{\circ} \mathrm{C}$, тривалість - 20 год). Морфологічні дослідження ооцитів проводили під мікроскопом МБС-10. Визначали стан зародкового пухирця, перивітелінового простору та цитоплазми, а саме щільність, 
ступінь гранульованості, ознаки фрагментації й дегенерації. Після 2 год культивування підраховували ооцити (\% до загальної кількості), що відновлювали мейотичне дозрівання (BM) та перебували на стадії метафази I (розчинення зародкового пухирця), а після 20 год - на стадії метафази II (завершували перший поділ мейозу й формували перше полярне тільце (ПТ)), а також ооцити з атиповою морфологією (нерівномірно гранульованою цитоплазмою та ознаками фрагментації останньої).

Метод прижиттєвого подвійного забарвлення флуоресцентними барвниками. Оцінку апоптотичної й некротичної загибелі фолікулярних клітин здійснювали за морфологічними ознаками за допомогою методу прижиттєвого подвійного забарвлення флуоресцентними барвниками нуклеїнових кислот Хехст 33342 та пропідіум йодид. Морфологічні дослідження проводили за допомогою люмінесцентного мікроскопа Люмам И-1 з водно-імерсійним об' єктивом х85. Використовували відеосистему передачі зображення з мікроскопа на комп'ютер. Визначали відсоток живих, апоптотичних $\mathrm{i}$ некротичних клітин при підрахунку не менше ніж 200 клітин.

Метод фазографічного аналізу в дослідженні скоротливої активності міометрію матки. Для дослідження скоротливої активності оваріального (ОВ) та цервікального (ЦВ) відділів міометрію матки застосовували метод фазно-графічного аналізу. Для кількісної характеристики спонтанних фазних скорочень узято такі параметри скоротливої активності: Fmax - пік амплітуди скорочення відносно базального тонусу, $м H$; $C$ vmax - позитивний пік першої похідної скорочення (макс. швидкість скорочення), $s H / c$; Rvmax - негативний пік першої похідної скорочення (макс. швидкість розслаблення), $s H / c ; \mathrm{T}$ - час, між максимальною активацією (CVmax) і дезактивацією (RVmax) скорочення (c); індекс скоротливості (IC - індекс скоротливості, розраховували як добуток Fmax на CVmax/RVmax, $\mathrm{mH}$ ).

Смужки міометрію матки відпрепаровували від сполучної тканини під мікроскопом МБС-10 і переносили в розчин Кребса $\left(4^{\circ} \mathrm{C}\right)$. Для реєстрації сили ізометричних скорочень ОВ і ЦВ міометрію матки, які вирізали з ендометрієм уздовж рогів матки під мікроскопом МБС-10 (довжиною до 10 мм і шириною не більше 1 мм, до 4 з одного рогу) переносили в камеру, фіксували й з'єднували 3 консолею механоелектричного перетворювача сили в електричний сигнал. Камеру перфузуватимуть розчином Кребса $\left(37^{\circ} \mathrm{C}\right.$, pH 7,29). Силу ізометричних скорочень реєстрували за допомогою швидкодіючого самописця Н3021-3. Рівномірність перфузії препарату, омиваючими розчинами забезпечували перистальтичним насосом НП-1М.

Серія друга. Досліджували вплив AgNPs на пре- та постімплантаційну смертність ембріонів. Групи тварин: 1 - контроль, уводили фіз. розчин $(\mathrm{n}=10), 2-\operatorname{AgNPs}(2$ мг/кг, n=10), 3 - AgNPs $(4$ мг/кг, $\mathrm{n}=10)$. Уведення речовин здійснювали щоденно протягом 10 днів у кожній групі тварин.

Оцінка показників ембріональної смертності в мищей. Самиць контрольних і дослідних груп парували з інтактними самцями. Спарювання та подальші маніпуляції з ембріонами проводили згідно 3 методикою [1]. Стадії розвитку пре- й постімплантаційних ембріонів визначали за методикою [1]. Підраховували: А - кількість живих ембріонів, Б - число місць резорбції (число загиблих ембріонів), В - число жовтих тіл вагітності. Показники пре- й постімплантаційної загибелі обчислювали за формулами: $((\mathrm{B}-\mathrm{A}+\mathrm{Б}) / \mathrm{B}) \bullet 100 \% \mathrm{i}(\mathrm{Б} /(\mathrm{A}+\mathrm{Б})) \bullet 100 \%$.

Статистична обробка результатів. Результати експериментів статистично оброблялися за програмою GraphPad Prism 5.0 (GraphPad Software, San Diego, USA). Перевірку даних на нормальність розподілу виконували за тестом Колмогорова-Смирнова та порівнювали середні за t-критерієм Стьюдента. P<0,05 уважалося статистично вірогідним. Дані представлено як $\mathrm{M} \pm \mathrm{m}$ (середнє \pm стандартна похибка, $10 \geq \mathrm{n} \geq 4$ ).

Виклад основного матеріалу та обгрунтування отриманих результатів дослідження. Вилив AgNPs на апоптотичну й некротичну загибель фолікулярних клітин. Нами встановлено, що введення AgNPs (2 мг/кг та 4 мг/кг) викликає вірогідне зменшення кількості живих клітин фолікулярного оточення ооцитів. Отже, за умов одно-та п'ятикратного введення AgNPs (2 мг/кг і 4 мг/кг) збільшується кількість апоптотичних клітин, а при десятикратному - апоптотичних і некротичних клітин фолікулярного оточення ооцитів. 
Кількість клітини фолікулярного оточення ооцитів (живих, із морфологічними ознаками апоптотичної й некротичної загибелі) за умов уведення $\operatorname{AgNPs}(2 \mathrm{ma} 4 \mathrm{mz} / \mathrm{kz})(\mathrm{M} \pm m)$

\begin{tabular}{|c|c|c|c|c|}
\hline \multirow{2}{*}{ Доза } & Група тварин & Живі, \% & Апоптоз, \% & Некроз, \% \\
\hline \multirow{2}{*}{2 мг/кг } & Контроль & $84,0 \pm 3,37$ & $15,29 \pm 3,45$ & $0,71 \pm 0,76$ \\
\cline { 2 - 5 } & 1 -кратне & $70,57 \pm 2,37^{*}$ & $28,0 \pm 3,11^{*}$ & $1,43 \pm 0,79$ \\
\cline { 2 - 5 } & 5 -кратне & $66,20 \pm 1,64^{*}$ & $32,4 \pm 1,14^{*}$ & $1,40 \pm 1,14$ \\
\cline { 2 - 5 } & 10 -кратне & $62,80 \pm 1,64^{*}$ & $33,40 \pm 0,89^{*}$ & $3,80 \pm 0,84^{*}$ \\
\hline \multirow{2}{*}{4 мг/кг } & Контроль & $79,33 \pm 1,22$ & $19,0 \pm 0,89$ & $1,67 \pm 0,82$ \\
\cline { 2 - 5 } & 1 -кратне & $70,0 \pm 1,0^{*}$ & $28,20 \pm 1,48^{*}$ & $2,20 \pm 1,30$ \\
\cline { 2 - 5 } & 5 -кратне & $69,80 \pm 1,64^{*}$ & $28,00 \pm 2,35^{*}$ & $4,80 \pm 0,84 *$ \\
\cline { 2 - 5 } & 10 -кратне & $60,40 \pm 1,14^{*}$ & $34,80 \pm 1,48^{*}$ & 24 \\
\hline
\end{tabular}

Примітки. *-p<0,05; **-p<0,01 - вірогідність відмінностей середніх груп даних відносно таких величин у контрольній групі тварин $(n=8)$.

Вилив AgNP на мейотичне дозрівання ооцитів. Одно- та п'ятикратне введення AgNPs (2 мг/кг і 4 мг/кг) не впливало на відновлення мейозу (Метафаза I) та формування першого полярного тільця (Метафаза II) ооцитами. Десятикратне введення AgNPs (2 мг/кг і 4 мг/кг) призводило до зменшення кількості ооцитів, здатних до формування першого полярного тільця (Метафаза II), відповідно, до $36,78 \pm 2,83$ при $56,93 \pm 3,84 \%$ у контролі (p<0,01, n=8) і до $28,02 \pm 3,05$ при $56,63 \pm 4,24 \%$ у контролі $(\mathrm{p}<0,01, \mathrm{n}=8)$. Отже, десятикратне введення AgNPs (2 мг/кг та 4 мг/кг) призводить до пригнічення мейотичного дозрівання ооцитів у мишей.

Вилив AgNPs на скоротливість оваріального й цервікального відділів матки в мишей. Однократне введення AgNPs (2 мг/кг) не викликало статистично вірогідних відмінностей величин досліджуваних параметрів (амплітуди, IC, T, CVmax, RVmax і ЧC) скоротливості у ОВ та ЦВ матки. П'ятикратне введення AgNPs (2 мг/кг) викликало 1) в ОВ вірогідне зростання таких величин: IC до $3,12 \pm 0,58 \mathrm{мH}$ при $1,97 \pm 0,52 \mathrm{мH}$ у контролі (р<0,05), Т до $6,13 \pm 0,62$ с при $11,5 \pm 1,05$ с у контролі ( $<0,05)$, величини амплітуди та ЧС статистично не відрізнялася від даних у контролі; 2) у ЦВ підви-

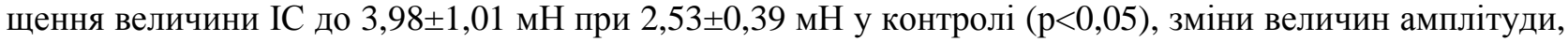
Т та ЧС не були статистично вірогідними. Десятикратне введення AgNPs (2 мг/кг) викликало 1) в ОВ

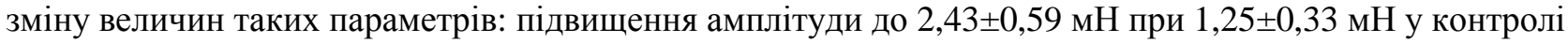

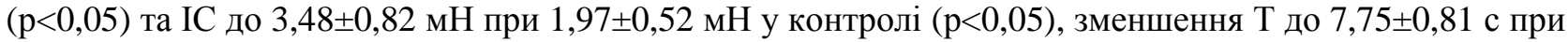
$11,5 \pm 1,05$ с у контролі (р<0,05); 2) у ЦВ зростання таких величин: амплітуди до $3,22 \pm 0,82 \mathrm{мH}$ при

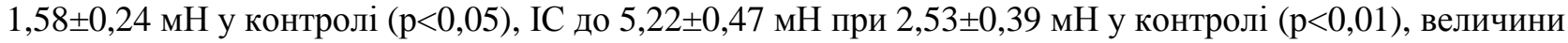
T та ЧС статистично не відрізнялися від даних у контролі. Отже, уведення AgNPs (2 мг/кг) викликає вірогідну зміну параметрів скоротливості матки: при п'ятикратному введенні - зростання IC та T, при десятикратному - зростання амплітуди і IC, зменшення T.

Дані про однократне, п’яти- й десятикратне введення AgNPs (4 мг/кг) представлено на рис. 1.

Отже, за умов п'яти- та десятиратного введення AgNPs (4 мг/кг) відбувається вірогідна зміна параметрів скоротливості матки: зростання амплітуди і IC.

Вилив AgNPs на показники ембріональної смертності. Дані про показники пре- й постімплантаційної смертності представлено в табл. 2.

За умов десятиратного введення AgNPs (2 мг/кг і 4 мг/кг) нами не встановлено вірогідних відмінностей величин показників ембріональної смертності контрольної та досліджуваних груп 

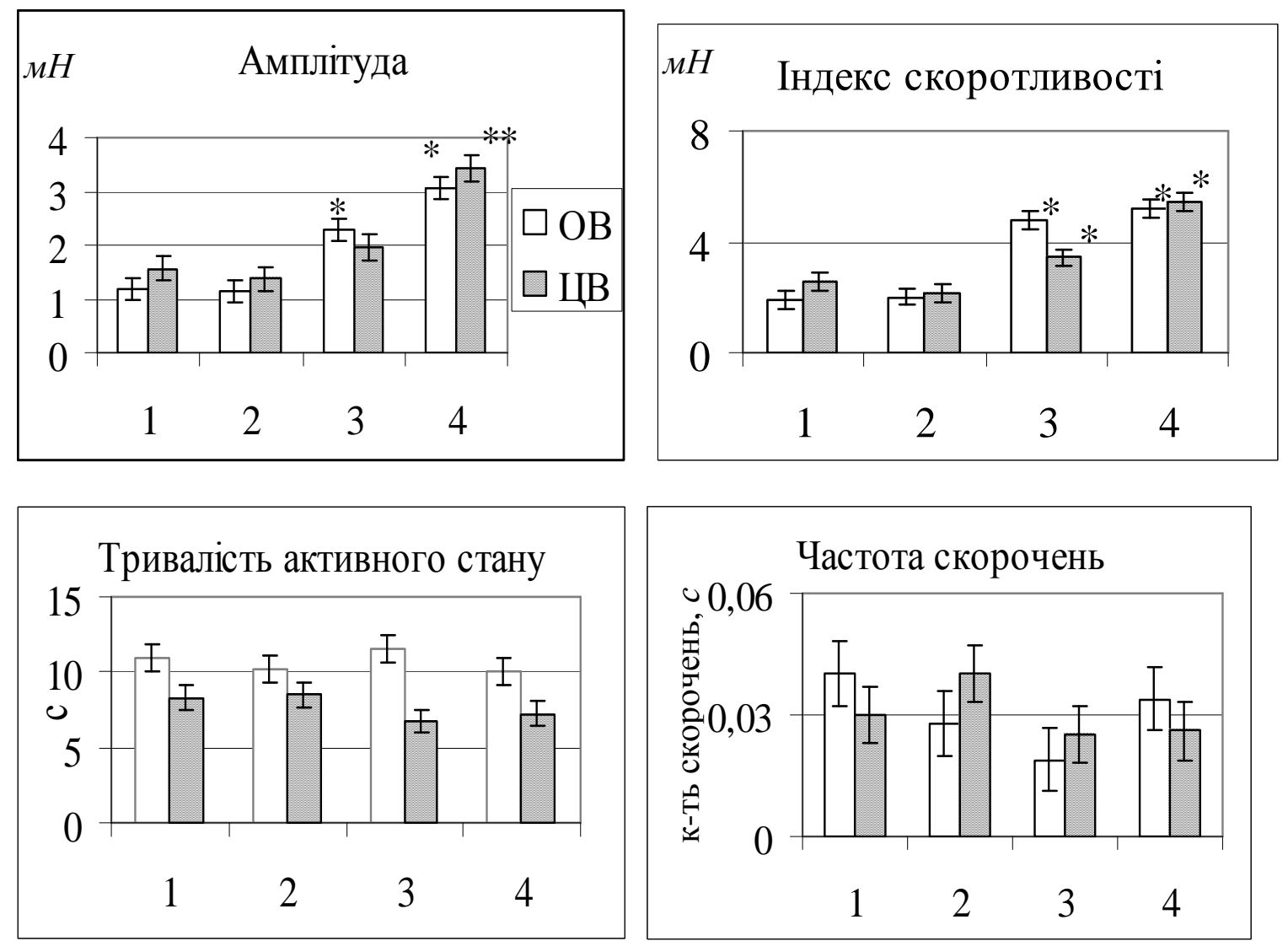

Рис. 1. Вплив уведення AgNPs (4 мг/кг) на скоротливість оваріального й ичервікального відділів матки (n=8)

Примітка. Групи тварин: 1 - контроль; 2 - однократне AgNPs (4 мг/кг); 3 - n'ятикратне AgNPs (4 мг/кг); 4 - десятикратне AgNPs (4 мг/к2). *-- p<0,05; ** - p<0,01 - вірогідність відмінностей середніх груп даних відносно таких величин у контрольній групі тварин

Таблиия 2

\section{Пре- й постімплантаційна ембріональна смертність у мишей за умов уведення $\operatorname{AgNPs}(2$ та 4 мг/кг) $(M \pm m)$}

\begin{tabular}{|l|c|c|c|}
\hline \multicolumn{1}{|c|}{ Показник смертності } & \multirow{2}{*}{ Контроль } & $\begin{array}{c}\text { Десятикратне } \\
\mathbf{2} \text { мг/кг }\end{array}$ & $\begin{array}{c}\text { Десятикратне } \\
\mathbf{4} \text { мг/кг }\end{array}$ \\
\hline Преімплантаційна & $2,76 \pm 0,74$ & $3,25 \pm 1,36$ & $4,34 \pm 2,22$ \\
\hline Постімплантаційна & $1,38 \pm 0,37$ & $1,51 \pm 0,68$ & $2,17 \pm 1,12$ \\
\hline
\end{tabular}

Обговорення результатів. $Є$ дані, що певні частинки срібла (41,6 $\pm 9,1$ нм AgNPs у концентрації 0,2 нM) можуть проникати в хоріон за допомогою дифузії через канали хоріона [4], а, проникнувши в хоріон, швидкість розчинення може бути набагато вищою, порівняно з такою у воді [4]. Проте нами отримано дані, що показники ембріональної смертності не змінювалися за умов десятикратного введення $\operatorname{AgNPs~(2~мг/кг~та~} 4$ мг/кг) й узгоджуються з даними [5], підтверджуючи положення, що ембріони можуть мати потенціал для розгортання компенсаторних механізмів за умов дії Ag у дозах нижче тих, що викликають явну токсичність.

Те, що нами не виявлено відмінностей у показниках смертності ембріонів між групами, підтверджує, що досліди проведено з концентраціми AgNPs нижче тих, що викликають явну токсичність. А також узгоджується з [5], що токсичності AgNPs i Ag великих розмірів на ембріони можуть бути пов'язані 3 токсичністю вільного $\mathrm{Ag}+$, а також це ще один доказ на користь гіпотези, що токсичність AgNPs переважно пов'язана з біодоступністю Ag+. Важливо відзначити, що наші дані свідчать, що й ооцити у ссавців мають потенціал для розгортання компенсаторних механізмів за умов дії Ag у дозах, нижчих за ті, що викликають явну токсичність. 
Імовірно, диференційна токсичність наносрібла може бути пов'язана з різними покриттями, які часто застосовуються на поверхні AgNPs, щоб їх стабілізувати [2]. Крім того, для характеристики НЧ із необхідністю враховують розмір, форму, кристалічну структуру, агрегацію, хімічний склад, поверхневі властивості (поверхневий заряд, площа поверхні), розчинність і пористість.

Для вияснення механізмів, що лежать в основі впливу AgNPs на гермінативні та соматичні клітини, потрібні подальші дослідження з використанням AgNPs різних розмірів і з різними покриттями.

Висновки й перспективи подальших досліджень. Однократне й п'ятикратне введення AgNPs (2 мг/кг, 4 мг/кг) не викликає запалення, не впливає на ооцити, змінює функціонування фолікулярних клітин і функціональний стан матки.

10-ти кратне введення AgNPs (2 мг/кг, 4 мг/кг) призводить до розвитку запальної реакції й пригнічує оваріальну функцію (формування полярного тільця ооцитів, збільшує кількість апоптотичних і некротичних клітин у фолікулярному оточенні ооцита), змінює функціональний стан матки (зростає скоротливість оваріального та цервікального відділів матки), проте не впливає на розвиток пре- й постімплантаційних ембріонів.

Висловлюємо подяку співробітнику відділу колоїдної технології природних систем Інституту біоколоїдної хімії ім. Ф. Д. Овчаренка НАН України, канд. біол. наук Л. С. Рєзніченко за надану субстанцію наночастинок срібла, синтезовану в Інституті біоколоїдної хімії ім. Ф. Д. Овчаренка НАН України.

\section{Джерела та література}

1. Манк А. Биология развития млекопитающих. Методы / А. Манк. - М. : Мир, 1990. - 406 с.

2. Chernousova S. Silver as antibacterial agent: ion, nanoparticle, and metal / S. Chernousova, M. Epple // Angew. Chem. Int. Ed. Engl. - 2013. - 4; 52(6). - P. 1636-1653.

3. Environmental transformations of silver nanoparticles: impact on stability and toxicity / C. Levard, E. Hotze, G. Lowry, G. Brown // Environ. Sci. Technol. - 2012. - 46(13). - P. 6900-6914.

4. In vivo quantitative study of sized-dependent transport and toxicity of single silver nanoparticles using zebrafish embryos / K. Lee, L. Browning, P. Nallathamby [et al.] // Chem. Res. Toxicol. - 2012. - 25(5). P. 1029-1046.

5. Molecular Mechanisms of Toxicity of Silver Nanoparticles in Zebrafish Embryos / van Aerle, A. Lange, A. Moorhouse [et al.] // Environ. Sci. Technol. - 2013. - 47 (14). - P. 8005-8014.

6. Silver nanoparticles: Behaviour and effects in the aquatic environment / J. Fabrega, S. Luoma, C. Tyler [et al.] // Environ. Int. - 2011. - 37 (2). - P. 517-531.

Литвиненко Алина, Ступчук Мария, Блашкив Орест, Вознесенська Татьяна. Морфофункциональное состояние женской репродуктивной системы в условиях применения наночастиц серебра. В условиях одно-, пяти- и десятикратного введения наночастиц серебра (2 мг/кг и 4 мг/кг) оценивали мейотическое созревание ооцитов, а также в условиях десятикратного введения (2 мг/кг и 4 мг/кг ) - пре- и постимплантационную смертность эмбрионов у мышей.

Исследования (две серии) проведены на самках белых лабораторных мышей восьми недель (16-18 г). Используемые наночастицы серебра (AgNPs, 30 нм, концентрация - 8 мг/мл за металлом, форма - сферическая).

Установлено, что однократное и пятикратне введение AgNPs (2 мг/кг, 4 мг/кг) не вызывает воспаления, не влияет на ооциты, изменяет функциональное состояние фолликулярных клеток и сократительность матки.

10-ти кратное введение AgNPs (2 мг/кг, 4 мг/кг) вызывает развитие воспалительной реакции и угнетает формирование полярного тельца ооцитами, увеличивается количество апоптотических и некротических клеток в фолликулярном окружении ооцита, изменяется функциональное состояние матки (возрастает сократимость овариального и цервикального отделов матки), однако не влияет на развитие пре- и постимплантационных эмбрионов.

Для выяснения механизмов, лежащих в основе влияния AgNPs на герминативные и соматические клетки, необходимы дальнейшие исследования с использованием AgNPs разных размеров и с разными покрытиями.

Ключевые слова: ооциты, матка, эмбрионы, наночастицы серебра.

Lytvynenko Alina, Stupchuk Mariya, Blashkiv Orest, Voznesenskaja Tetyana. Functional Status of Reproductive System Under Treatment of Silver Nanoparticles in Female Mice. The effect of AgNPs on mammalian cells and tissues requires further study. The effect of AgNPs on the functional status of the female reproductive system of mammals has not been examined yet. 
The aim is under condition of the intravenous treatment of silver nanoparticles (AgNPs) to estimate the functional status of the reproductive system in female mice, namely to assess meiotic maturation of oocytes, viability of follicular cells surrounding the oocyte, spontaneous contractile activity of the myometrium and pre-and postimplantation mortality of embryos.

Research (two series) has been done on white laboratory 8 weeks (16-18 g) mice female in compliance with all requirements for work with laboratory animals (International European Convention for the Protection of Vertebrate Animals, Strasbourg, 1986).

First series. AgNPs are spherical nanoparticles of $30 \mathrm{~nm}(8 \mathrm{mg} / \mathrm{ml}$ for metal $)$ diluted in water for injection. Method of treatment: intravenous. It has been investigated two doses of $2 \mathrm{mg} / \mathrm{kg}$ and $4 \mathrm{mg} / \mathrm{kg}$. Frequency of treatment: one time per day of each dose of 1,5 and 10 times ( $n=8$ animals in each group). Control animals injected with saline. Material for the study (ovaries, uterus) were taken the day after the last AgNPs injection.

Oocytes cultivation. The oocytes have been isolated mechanically from the ovaries of mice in a non-enzymatic way (without cumulus cells and in cumulus-oocyte-cell complexes). The mice oocytes from one group were collected and distributed into separate chambers, 10-20 oocytes each. All control and experimental oocytes were cultured under the same conditions (a sterile box, cameras with $0.4 \mathrm{ml}$ culture medium DME and $15 \mathrm{mM}$ HEPES, Ca2+ concentration of $1,71 \mathrm{mM}$, temperature $37^{\circ} \mathrm{C}$, duration 20 hours). Morphological study of oocytes was performed under a microscope MBS10 after 2 hours of cultivation (\% of total): the oocytes which restored the meiotic maturation (BM) and were at metaphase I stage (germinal vesicle break-down), and after 20 hours were at metaphase II stage (completed by the first division of meiosis and formed the first polar body (PB)) and oocytes with atypical morphology (unevenly granulated cytoplasm and fragmentation characteristics of the latter) have been counted.

Method color fluorescent dyes. The estimation of apoptotic and necrotic death of follicular cells was performed by morphological characteristics using the method of in vivo dual-color fluorescent dye nucleic acids Hoechst 33342 and propidium iodide. Morphological studies were performed using a fluorescent microscope with water-immersion at x85. There has been used a video system sending the image from the microscope to the computer. The percentage of the living, apoptotic and necrotic cells has been determined by counting at least 200 cells.

The method of phase-graphical analysis in the study of the contractile activity of the uterine myometrium. To investigate the contractile activity of the ovarian (OD) and cervical (CD) uterine myometrium departments the method of phase-graphic analysis has been used (Gullam J., Blanks A., Thornton S., Shmygol A. 2009). To characterize the spontaneous emission by quantity of the following parameters contractile activity were taken into consideration: amplitude of reduction $(\mathrm{mN})$, frequency of reduction (number per second), duration of contraction and relaxation (sec), speed reduction and relaxation $(\mathrm{mN} / \mathrm{second})$; index of contractility ( $\mathrm{IC}$ » index of contractility, was calculated as the product of Fmax on CVmax/RVmax, $\mathrm{mN}$ ).

Strips of uterine myometrium have been separated from the connective tissue under the microscope MBS-10 and transferred to Krebs solution $\left(4^{\circ} \mathrm{C}\right)$. To register isometric force of reduction agents and CD myometrium of the uterus, which was being cut off with the endometrium along the uterine horns (up to $10 \mathrm{~mm}$ and a width of less than $1 \mathrm{~mm}$ to 4 from one horn), transferred into the camera and fixed. The Krebs solution $\left(37^{\circ} \mathrm{C}, \mathrm{pH} 7,29\right)$ was used as perfusion solution in a camera. The force of isometric contractions was recorded using the high-speed recorder. Uniformity of preparation perfusion with washing solutions was provided by the peristaltic pump НП-1M.

Second series. There has been investigated the effect of AgNPs on pre- and post-implantation embryo mortality. Groups of animals: $1-\operatorname{control}(\mathrm{n}=10), 2-\operatorname{AgNPs}(2 \mathrm{mg} / \mathrm{kg}, \mathrm{n}=10), 3-\operatorname{AgNPs}(4 \mathrm{mg} / \mathrm{kg}, \mathrm{n}=10)$.

Fetal mortality in mice. Female control and experimental groups crossed with intact males. Counted: A - number of live embryos; B - number of seats of resorption (number of dead embryos); $\mathrm{B}$ - number of corpora lutea of pregnancy. Indicators of pre-and post-implantation death was calculated using the formula: $((\mathrm{B}-\mathrm{A}+\mathrm{B}) / \mathrm{B}) \bullet 100 \%$ and $(\mathrm{B} /(\mathrm{A}+\mathrm{B})) \cdot 100 \%$.

Statistical analysis. For the statistical analysis of the results the software package Origin 8Pro (OriginLab Corp., North., MA, USA) and spreadsheets «Microsoft®Excel2003» have been used. The reliability of the difference of mean values determined by Student's t-test, considering to be reliable the values of $p<0,05$. The statistical analysis of the results of research conducted by using analysis of variance ANOVA followed by comparison of mean values between groups by Newman-Coles test using the statistic program-6.

Results. Established that single input and five-time AgNPs treatment $(2 \mathrm{mg} / \mathrm{kg}, 4 \mathrm{mg} / \mathrm{kg})$ does not cause inflammation and does not affect oocytes but changes follicular cells functional state and alters functional state of the uterus. Ten-time AgNPs treatment $(2 \mathrm{mg} / \mathrm{kg}, 4 \mathrm{mg} / \mathrm{kg}$ ) inhibits the formation of ocyte first polar body in vitro, increases the number of apoptotic and necrotic cells in follicular environment of oocyte), changes the functional state of the uterus (increasing contractility of ovarian and cervical uterus departments), but does not affect the development of pre- and postimplantatsiynyh embryos but does not affect the development of pre- and postimplantation embryos.

Using AgNPs different sizes and with different coatings further studies are needed for the elucidation of mechanisms underlying exposure AgNPs in germ and somatic cells.

Key words: oocytes, uterus, embryos, AgNPs.

Стаття надійшла до редколегії 21.09.2016 р. 